\title{
PERUMUSAN SANKSI PIDANA DALAM PEMBENTUKAN PERATURAN PERUNDANG-UNDANGAN
}

\author{
Suhariyono AR \\ Pegawai Negeri Sipil pada Ombudsman Republik Indonesia \\ e-mail: suhariyono_ar@yahoo.com
}

\begin{abstract}
ABSTRAK
Perumusan sanksi pidana terkait dengan adanya larangan atau perintah dari suatu norma yang sebelumnya ada, atau disepakati oleh pembentuk undang-undang. Kesepakatan tersebut dapat diartikan sebagai suatu kebijakan kriminalisasi atau dekriminalisasi suatu perbuatan yang disebut dengan kebijakan penentuan pidana (criminal policy). Dalam hal menentukan unsurunsur tindak pidana dalam suatu perbuatan tidaklah sulit dibandingkan bagaimana menentukan bobot dan besaran sanksi pidana itu sendiri. Akhir-akhir ini, para pembentuk undang-undang sering dipengaruhi secara emosional untuk selalu membalas perbuatan yang dilarang atau yang diperintahkan dengan pidana penjara atau denda yang berat sehingga orang mengatakan bahwa pembentuk undang-undang masih berpegangan pada teori pembalasan (retributive view). Padahal, di negara lain, terutama di negara-negara maju, telah menerapkan keadilan restoratif (restorative justice) untuk tindak-tindak pidana ringan, korbannya telah memaafkan, pelakunya telah uzur, anak-anak atau perempuan hamil. Pemidanaan merupakan tindakan represif (penanganan atau penanggulangan). Selain mempunyai makna represif, pemidanaan mempunyai makna preventif dalam arti luas. Di satu pihak pemidanaan itu dimaksudkan untuk memperbaiki sikap atau tingkah laku terpidana sehingga kelak tidak akan mengulangi lagi perbuatannya, dan di lain pihak pemidanaan itu juga dimaksudkan untuk mencegah orang lain dari kemungkinan melakukan perbuatan yang serupa (pencegahan umum).
\end{abstract}

Kata kunci: kebijakan penentuan pidana, penghitungan bobot, pemidanaan yang ideal.

\begin{abstract}
The formulation of criminal sanctions dealing with prohibition or order from the first norm or has agreement from the former of legislation. The agreement is a kind of criminal policy. In determining of criminal aspects in action is not difficult compared with how to determine the heavy criminal sanction. Recently, the formers of legislation are often influenced by their emotional to revenge prohibited action or ordered action with jail or the heavy fine, thats why people say that the formers of legislation still hold on retributive view. Whereas, in other countries especially in din developing countries have implemented restorative justice, for the light crimes, the victim has forgiven, the criminals are old, children or pregnant women. The criminal is a kind of implementation of criminal law in general people say as repressive action. Besides, having meaning for repressive action, criminal has also wide meaning for preventive action. In one hand, the criminal is used for improving behavior so that they do not do crime anymore.
\end{abstract}

Keywords: determination of criminal policy, counting of heavy, ideal criminal.

\section{PENDAHULUAN}

\section{Penggunaan Hukum}

Salah satu politik hukum, dalam penyusunan suatu Rancangan Undang-Undang (yang selanjutnya disebut RUU), merupakan penentuan sanksi pidana, baik penentuan pidana mati, pidana penjara, pidana kurungan, maupun pidana denda, termasuk pidana tambahannya. Dalam penentuan sanksi pidana, selain memahami kriminalisasi dan dekriminalisasi beberapa perbuatan tertentu, dituntut adanya penelitian dan pemikiran terhadap masalah kebijakan penentuan pidana (criminal policy).

Terkait dengan penentuan pidana suatu perbuatan yang dikriminalisasi, Sudarto mengingatkan bahwa (Sudarto, 1986:35-41): 1. Penggunaan hukum pidana harus memperhatikan tujuan pembangunan nasional, yaitu mewujudkan masyarakat adil makmur yang merata materiel dan spiritual berdasarkan Pancasila; 
sehubungan dengan itu maka (penggunaan) hukum pidana bertujuan untuk menanggulangi kejahatan dan juga mengadakan pengugeran terhadap tindakan penanggulangan itu sendiri, demi adanya kesejahteraan dan pengayoman masyarakat; 2. Perbuatan yang diusahakan untuk dicegah atau ditanggulangi dengan hukum pidana harus merupakan "perbuatan yang dikehendaki" yaitu perbuatan yang mendatangkan kerugian (materiil dan atau spiritual) atas warga masyarakat; 3 . penggunaan hukum pidana harus pula memperhitungkan prinsip "biaya dan hasil" (cost and benefit principle); 4. Penggunaan hukum pidana harus pula memperhatikan kapasitas atau kemampuan daya kerja dari badan-badan penegak hukum, yaitu jangan sampai ada kelampauan beban tugas (overbelasting);

Pada umumnya, pembentuk undang-undang selalu mengatakan bahwa salah satu usaha penanggulangan kejahatan adalah dengan menggunakan hukum pidana dan sanksinya berupa pidana. Namun demikian, tujuan yang bagaimana yang ingin dicapai orang dengan suatu pidana itu, sampai sekarang belum terdapat kesamaan pendapat di antara para sarjana. Dalam praktik pemidanaan yang ada di Indonesia, dapat diketahui bahwa pemikiran orang mengenai pidana dan pemidanaan dewasa ini sedikit banyak masih dipengaruhi oleh pemikiran-pemikiran pada beberapa abad yang lalu (retributif), walaupun sekarang ini sudah mulai berubah sesuai dengan perkembangan zaman, ilmu pengetahuan yang baru, terutama ilmu kriminologi, dan adanya pembaruan-pembaruan dalam sistem pemidanaan di berbagai negara.

Pada dasarnya, pidana itu ditujukan sebagai suatu penderitaan atau nestapa bagi pelaku tindak pidana atas kesalahannya. Adanya penderitaan tersebut dalam bentuk pidana telah mengakibatkan hukum pidana mendapatkan tempat tersendiri di antara hukum yang lain, yang mana menurut pendapat para sarjana, hukum pidana itu dipandang sebagai ultimum remedium atau sebagai upaya terakhir yang harus dipergunakan untuk memperbaiki tingkah laku manusia (P.A.F. Lamintang, 1983:16-17). Van Bemmelen menyatakan bahwa hukum pidana itu mempunyai tempat sendiri dibandingkan dengan hukum yang lain karena negara diberi kekuasaan untuk menimbulkan penderitaan dengan sengaja (Van Bemmelen, 1984:13). Wajar jika orang menghendaki agar hukum pidana itu di dalam penyusunan (pembentuk undang-undang) dan penerapannya harus disertai dengan pembatasan yang ketat, dalam arti yang rasional dan proporsional.

Hukum pidana sebagai ultimum remedium, harus disadari bahwa selain memperhatikan hal di atas (rasional dan proporsional), pembentuk undangundang juga harus mempertimbangkan mengenai perbuatan yang akan dijadikan tindak pidana dan sanksi apa yang sebaiknya digunakan atau dikenakan kepada pelaku. Pada saat pembentuk undang-undang menetapkan untuk adanya sanksi pidana dalam suatu undang-undang, maka kebijakan penentuan pidana tersebut tidak terlepas dari kebijakan penghilangan kemerdekaan atau pembebanan hak seseorang yang langsung terkait dengan hak asasi manusia (yang selanjutnya disebut HAM) yang dilegalisasi.

Dalam tulisan ini, selain mengingatkan kembali bagi pembentuk undang-undang agar berhati-hati dalam merumuskan ketentuan sanksi pidana yang rasional dan proporsional, juga akan dikemukakan bagaimana cara dan teknik perumusannya, termasuk mengenali unsur-unsur tindak pidana yang akan dituangkan dalam ketentuan sanksi pidana.

\section{Kebijakan Penentuan Pidana (Criminal Policy)}

Masalah penentuan pidana tidak terlepas dari pembentukan suatu undang-undang, yang mana pada dasarnya merupakan suatu kebijakan politik negara atau kebijakan hukum yang dibentuk oleh Dewan Perwakilan Rakyat dan Presiden. Di sini hukum tidak dapat hanya dipandang sebagai pasal-pasal yang bersifat imperatif atau keharusan-keharusan yang bersifat das sollen, melainkan harus dipandang sebagai subsistem yang dalam kenyataan (das sein) bukan tidak mungkin sangat ditentukan oleh politik, baik dalam perumusan materi dan pasal-pasalnya maupun dalam implementasi dan penegakannya.

Sudarto berpendapat bahwa politik hukum adalah usaha untuk mewujudkan peraturan-peraturan yang baik sesuai dengan keadaan dan situasi pada suatu saat dan kebijakan dari negara melalui badan-badan yang berwenang untuk menetapkan peraturan-peraturan yang dikehendaki yang diperkirakan bisa digunakan untuk mengekspresikan apa yang terkandung dalam masyarakat dan untuk mencapai tujuan apa yang dicita-citakan (Sudarto, 1986:20).

Kebijakan, dalam pengertian yang selama ini dipahami oleh masyarakat umum, terutama dalam bidang kepemerintahan adalah policy, yang dapat diartikan sebagai the general principle by which a government is guided in it's management of public affairs, or the legislature in it's measures (Henry Cambell Black, 1979) (sebuah prinsip umum yang mana digunakan sebagai pedoman oleh pemerintah dalam manajemen penyelenggaraan urusan publik atau dalam pembentukan perundang-undangan). Kebijakan penentuan pidana adalah prinsip umum 
yang digunakan oleh pembentuk undang-undang dalam menentukan pidana dengan dasar-dasar yang rasional, proporsional, fungsional, dan tetap mengacu pada asas yang ditetapkan dalam ketentuan umum, baik yang ditentukan dalam Buku I Kitab UndangUndang Hukum Pidana (yang selanjutnya disebut KUHP) maupun pedoman-pedoman umum untuk pembentukan peraturan perundangan yang berlaku. Peter Hoefnagels berpendapat, bahwa kebijakan penentuan pidana atau dikenal dengan criminal policy mempunyai ruang lingkup yang cukup luas, yang meliputi penerapan hukum pidana, pencegahan tanpa pidana, dan pengaruh pandangan masyarakat terhadap kejahatan dan pemidanaan melalui massmedia (Peter Hoefnagels, 1969:56-57).

Kebijakan penentuan pidana dapat diartikan sempit dan luas. Dalam arti sempit adalah keseluruhan asas dan metode yang menjadi dasar dari reaksi terhadap pelanggaran hukum yang berupa pidana. Kebijakan kriminal dalam arti luas adalah keseluruhan fungsi dari aparatur penegak hukum, termasuk di dalamnya cara kerja dari pengadilan dan polisi. Dalam arti yang paling luas adalah keseluruhan kebijakan yang dilakukan melalui perundang-undangan dan badanbadan resmi yang bertujuan untuk menegakkan norma dalam masyarakat jika terjadi pelanggaran.

Bila dilihat dari lingkup di atas, pada dasarnya penanggulangan kejahatan secara garis besar dapat dibagi menjadi dua, yakni lewat jalur penal atau hukum pidana dan lewat jalur nonpenal atau bukan hukum pidana. Jalur nonpenal meliputi pencegahan tanpa pidana, dan pengaruh pandangan masyarakat terhadap kejahatan dan pemidanaan melalui mass media. Jalur penal adalah melalui penerapan hukum pidana yang pada umumnya orang menyebut sebagai tindakan represif (penanganan atau penanggulangan). Selain mempunyai makna represif, jalur penal mempunyai makna preventif dalam artian luas. Di satu pihak pemidanaan itu dimaksudkan untuk memperbaiki sikap atau tingkah laku terpidana sehingga kelak tidak akan mengulangi lagi perbuatannya, dan di lain pihak, pemidanaan itu juga dimaksudkan untuk mencegah orang lain dari kemungkinan melakukan perbuatan yang serupa (pencegahan umum). Oleh karena itu, pandangan yang terakhir ini dianggap berorientasi ke depan (forward-looking).

Pada umumnya, pandangan yang terakhir di atas dianggap lebih ideal dalam rangka penerapan gagasan pemidanaan, dibandingkan dengan pandangan pertama yang masih dianggap backward-looking. Pandangan yang bersifat preventif atau pembinaan yang ada pada dewasa ini dianggap lebih modern sehingga banyak mempengaruhi kebijakan penentuan pidana di berbagai negara-negara di dunia, termasuk Indonesia.

Sebagaimana dapat dipahami bahwa upaya dalam penanggulangan kejahatan melalui jalur nonpenal lebih bersifat tindakan pencegahan untuk terjadinya kejahatan, maka sasaran utamanya adalah menangani faktor-faktor kondusif penyebab terjadinya kejahatan. Faktor-faktor kondusif tersebut antara lain berpusat pada masalah atau kondisi sosial atau ekonomi yang mana secara langsung atau tidak langsung dapat menimbulkan kejahatan.

Dari gambaran tersebut di atas, pada dasarnya upaya nonpenal yang paling strategis adalah segala daya upaya untuk menjadikan masyarakat sebagai lingkungan sosial dan lingkungan hidup yang sehat, baik materiel maupun immateriel dari faktor-faktor kriminogen. Dengan demikian, masyarakat dengan seluruh potensinya harus dijadikan sebagai faktor penangkal kejahatan atau faktor "anti kriminogen" yang merupakan bagian integral dari keseluruhan kebijakan penentuan pidana. Beberapa negara di Eropa,misalnya, penentuan pidana mati sama sekali dilarang karena dinilai melanggar HAM dan penentuan pidana penjara disana sudah tidak sepopuler seperti di negara-negara berkembang.

Di Belanda, telah berkembang adanya pengaturan dan juga penerapan secara konsisten penyelesaian perkara di luar sidang pengadilan (afdoening buiten process). Disana, peran Jaksa Penuntut Umum, dalam hal penyelesaian perkara di luar sidang pengadilan, diberikan tempat oleh undang-undangnya, untuk dapat menjatuhkan pidana denda bagi pelaku tindak pidana dalam kasus individual. Ada dua metode diversi dalam proses peradilan pidana di Belanda, yakni nonpenuntutan pidana, dan transaksi (tawarmenawar) dalam penyelesaian perkara di luar sidang pengadilan.

Transaksi dapat dipertimbangkan sebagai bentuk diversi yang oleh pelaku secara sukarela membayar sejumlah uang kepada negara, memenuhi satu atau lebih persyaratan finansial yang ditetapkan oleh penuntut umum dalam rangka menghindari penuntutan tindak pidana dan pengadilan lebih lanjut. Transaksi ini dikenal sejak 1838 pada kasus finansial (keuangan). Pada tahun 1983, pembayaran atau penetapan pada suatu kasus finansial semata-mata menangguhkan untuk pelanggaran ringan yang secara prinsip hanya dipidana dengan denda. Pasal 74 PC menentukan bahwa transaksi dapat dilakukan untuk tindak pidana yang diancam kurang dari 6 tahun, dengan syarat: 1 . Pembayaran sejumlah uang ke negara, asalkan jumlah uang tersebut tidak kurang dari 5 Gulden dan tidak 
lebih dari maksimum denda yang ditentukan undangundang; 2 . Penyangkalan atas benda yang telah disita atau dalam penyitaan; 3 . Penyerahan benda atas penyitaan atau pembayaran pada negara atas harga yang dinilai; 4. Pembayaran penuh kepada negara sejumlah uang atau mentransfer benda yang disita dari terdakwa, sebagian atau seluruhnya, taksirantaksiran perolehan yang diperoleh (dengan memakai) atau berasal dari tindak pidana, termasuk biaya yang disimpan; 5. Seluruh atau sebagian kerugian atas kerusakan yang disebabkan oleh tindak pidana

Di Belanda, transaksi ini hampir sama dengan $a$ plea-bargaining system, dan hampir $90 \%$ semua tindak pidana dibawa dalam lingkup transaksi. Lebih dari $35 \%$ semua tindak pidana diselesaikan berdasarkan transaksi oleh jaksa. Untuk meminimalisasi resiko, perhitungan dan keseragaman pelaksanaan transaksi dikeluarkan petunjuk pelaksanaan untuk tindak pidana biasa yang sering dilakukan transaksi, misalnya, pencurian ringan, transaksinya antara 45-350 Euro; pencurian sepeda, transaksinya 113-340 Euro. Tindak pidana yang sering ditransaksikan adalah mabuk di depan umum dan pengutil. Polisi juga dapat melakukan transaksi, namun jumlahnya dibedakan dengan jaksa, yakni maksimumnya 350 Euro, sedangkan jaksa maksimum transaksinya adalah 450.000 Euro (Peter J.P. Tak, 2002:22).

Berdasarkan transaksi di atas, dewan jaksa penuntut umum (Board of Prosecutor General) mengeluarkan petunjuk pelaksanaan nasional. Petunjuk pelaksanaan tersebut didasarkan pada kepentingan umum, misalnya (Peter J.P. Tak, 2002:21): 1. Selain sanksi, hukuman yang dipandang lebih baik atau akan lebih efektif, misalnya, tindakan disiplin, administratif, dan juga tindakan perdata; 2 . Penuntutan akan menjadi tidak proporsional, tidak adil, atau tidak efektif dikaitkan dengan jenis kejahatan yang tidak mengakibatkan kerugian dan tidak layak untuk dikenai hukuman; 3. Penuntutan akan menjadi tidak proporsional, tidak adil, atau tidak efektif bila dikaitkan dengan pelaku kejahatan, misalnya umurnya, kesehatan, prospek penyembuhan, atau pelaku pertama; 4. Penuntutan menjadi bertentangan dengan kepentingan negara, seperti halnya alasan keamanan, ketenteraman dan juga ketertiban, atau jika ada peraturan baru yang diintrodusir; 5. Penuntutan akan menjadi bertentangan dengan kepentingan korban, misalnya ganti kerugian telah dibayar.

Di Indonesia, Pasal 82 KUHP juga menganut penyelesaian perkara di luar peradilan. Pasal 82 ayat 1 KUHP berbunyi "Kewenangan menuntut pelanggaran yang diancam dengan pidana denda saja menjadi hapus, kalau dengan suka rela dibayar maksimum denda dan biaya-biaya yang telah dikeluarkan kalau penuntutan telah dimulai, atas kuasa pejabat yang ditunjuk untuk itu oleh aturan-aturan umum, dan dalam waktu yang ditetapkan olehnya". Selanjutnya ayat 2 menentukan: "Jika di samping pidana denda ditentukan perampasan, maka barang yang dikenai perampasan harus diserahkan pula, atau harganya harus dibayar menurut taksiran pejabat sebagaimana dimaksud pada ayat $1 "$.

Bila dihubungkan dengan perkembangan tujuan dan bentuk-bentuk pidana dan pemidanaan di atas, maka dengan pendekatan restorative justice (keadilan restoratif) akan lebih cocok jika diterapkan dalam hal memulihkan keseimbangan (evenwicht, harmonie) antara dunia lahir dan dunia gaib, antara golongan manusia seluruhnya dan juga orang perseorangan, antara persekutuan dan teman sejawatnya dalam kehidupan alam pikiran tradisional Indonesia yang bersifat kosmis. Pemikiran ini, salah satunya telah dikembangkan melalui pembentukan Undang-Undang tentang Sistem Peradilan Pidana Anak, yang minggu lalu telah disetujui oleh rapat Paripurna DPR-RI.

Barb Toews, dalam bukunya The Little Book of Restorative Justice for People in Prison mengatakan bahwa kebanyakan orang berpendapat bahwa keadilan mengharuskan adanya suatu pembalasan, hukuman, dan pemenjaraan. Sistem peradilan pidana terpadu sering merespon hal seperti itu karena sistem tersebut mempercayai bahwa masyarakat yang bersalah harus dihukum karena kejahatannya. Namun demikian, hasil dari penghukuman justru akan mengakibatkan kerugian kepada pelaku, korban, keluarga pelaku, dan masyarakat sekitar. Untuk itu, keadilan restoratif yang dapat menjawab permasalahan tersebut (Barb Toews, 2006:5). Lebih lanjut dikatakan bahwa keadilan restoratif menawarkan suatu respons keadilan yang mencari perbaikan individu, pemulihan hubungan, dan memajukan atau mendorong kebaikan.

Konsep keadilan restoratif bila dikaitkan dengan hukum adat di atas, sama dekatnya dengan konsep penyelesaian perkara di luar pengadilan (afdoening buiten process) yang hampir sama dengan paradigma penghukuman keadilan restoratif dimana pelaku didorong untuk memperbaiki kerugian yang telah ditimbulkannya kepada korban, keluarganya, dan juga masyarakat. Suspended prosecution atau di Belanda dikenal dengan istilah seponeering, telah diterapkan di beberapa negara sebagai bentuk diversi yang mengarah pada model keadilan restoratif.

Hoefnagels mengingatkan bahwa "Punishment in criminal law is limited not only by effectiveness and 
purposefulness but above all by legality" (G. Peter Hoefnagels, 1969:139). Jadi, selain efektif, kebijakan penentuan pidana juga harus mempunyai tujuan yang penuh makna secara mendalam sebagai dasar berpijak untuk lebih berorientasi pada falsafah pemidanaan dan tujuan pemidanaan.

Belanda, dalam kultur pemidanaan (penal culture), yang lebih spesifik lagi mengenai budaya penjatuhan pidana (sentencing culture), dalam beberapa hal berbeda dengan Inggris dan Wales. Sistem Inggris mempunyai tradisi penjeraan, sedangkan di Belanda lebih pada humanitarian (cinta kasih atau manusiawi) yang dikombinasi dengan suatu kesadaran yang besar dari dampak pelaksanaan pemenjaraan yang destruktif. Di Belanda, ide penghukuman hanya tujuan akhir sebagai ultimum remedium. (Christopher Harding et al, 2002:319) Dalam perkembangannya, semua delik dalam KUHP Belanda dicantumkan ancaman pidana denda sebagai alternatif pidana penjara.

Prospek pengaturan pidana denda tidak hanya memfokuskan diri pada substansi hukum pidana, tetapi juga melihat pada pelaksanaan proses peradilan sebagai ujung tombak terciptanya rasa akan keadilan dalam masyarakat. Pembenahan terhadap penataan institusi atau lembaga dan sistem manajemen atau tata laksana yang mendukung sistem peradilan pidana dalam makna proses hukum yang adil atau layak. Diskresi kelembagaan termasuk diperhitungkan untuk melaksanakan keadilan restoratif dengan persyaratan tertentu, yang mana dibarengi dengan pengawasan, keterbukaan informasi, dan akuntabilitas penegak hukum.

Pembentuk undang-undang di Indonesia kini hanya perlu memilih, apakah masih memilih pandangan retributif atau pembalasan (retributive view) yang mana mengandaikan pidana sebagai ganjaran negatif terhadap setiap perilaku menyimpang yang dilakukan oleh warga masyarakat ataukah pandangan utilitarian (utilitarian view) yang lebih melihat pidana itu dari segi manfaat atau kegunaannya. Pandangan utilitarian melihat situasi atau keadaan yang ingin dihasilkan dengan dijatuhkannya pidana dan penjatuhan pidana tersebut harus dilihat dari segi tujuan, manfaat, atau kegunaannya untuk perbaikan dan pencegahan. Jadi, di satu sisi pemidanaan dimaksudkan untuk memperbaiki sikap atau tingkah laku terpidana sehingga kelak tidak akan mengulangi lagi perbuatan yang sama. Di sisi lain, pemidanaan dimaksudkan untuk mencegah orang lain dari kemungkinan melakukan perbuatan yang serupa.

Pada umumnya, pandangan utilitarian tersebut dianggap lebih ideal dalam rangka penerapan gagasan pemidanaan. Pandangan yang bersifat preventif dan pembinaan, dewasa ini dianggap lebih modern dan karena itu banyak mempengaruhi kebijakan penentuan pidana di berbagai negara. Selain pandangan di atas, Packer mempunyai pandangan lain yang disebut dengan pandangan behaviorial. Ia berpendapat bahwa pada dasarnya, behaviorial ini juga berorientasi ke depan, artinya pidana tidak dilihat sebagai pembalasan kepada penjahat, tetapi dilihat sebagai sarana untuk memperbaiki tingkah laku terpidana. Hanya saja, berbeda dengan pandangan utilitarian, pandangan kaum behaviorist ini didasari oleh paham determinisme yang ekstrem. Individu manusia dianggap sama sekali tidak mempunyai kehendak bebas dan karenanya tidak mungkin dituntut pertanggungjawaban moral yang tegas. Setiap perbuatan anti sosial yang dilakukan disebabkan oleh banyak faktor yang berada di luar kekuasaan individu itu sendiri.

Pandangan Muladi juga perlu dipertimbangkan dalam penentuan pidana karena Muladi mencoba melakukan integrasi antara ketiga pandangan tersebut yang disebut dengan teori tujuan pemidanaan yang integratif. Pandangan inilah yang dapat memenuhi fungsinya dalam rangka mengatasi kerusakan yang diakibatkan oleh tindak pidana (kemanusiaan dalam sistem Pancasila) (Muladi, 1992:53-54). Pilihan teori integratif ini dilakukan karena adanya pendekatan multi dimensional yang bersifat mendasar terhadap dampak pemidanaan, baik dampak yang bersifat individual maupun dampak yang bersifat sosial.

Perlu diingat juga, bahwa ancaman hukuman yang ditentukan dalam suatu undang-undang, pada umumnya menimbulkan pemaksaan psikologis bagi mereka yang akan atau telah melakukan pelanggaran pidana. Teori pemaksaan psikologis dimaksudkan bahwa ancaman hukuman itu harus dapat mencegah niat orang untuk melakukan kejahatan, dalam arti orang harus menyadari bahwa jika melakukan suatu kejahatan itu mereka pasti akan dipidana. Jadi, tujuan utama pidana adalah memaksa penduduk secara psikologis agar mereka itu jangan sampai melakukan tindakan yang bersifat melanggar hukum.

Berdasarkan hal tersebut, Anselm von Feuerbach berpendapat bahwa asas yang penting bagi pemberian ancaman pidana yakni setiap penjatuhan pidana oleh hakim haruslah merupakan suatu akibat hukum dari suatu ketentuan menurut undang-undang dengan maksud menjamin hak-hak yang ada pada setiap orang. Undang-undang harus memberikan suatu ancaman pidana berupa suatu penderitaan kepada setiap orang yang melakukan pelanggaran hukum (P.A.F. Lamintang, 1983:127-128). 
Tujuan pemidanaan yang dikembangkan oleh para pembentuk RUU KUHP tampaknya merupakan gabungan dari teori tujuan itu sendiri yakni pencegahan umum (generale preventie) terutama teori pencegahan umum secara psikologis (psychologische dwang) dan pencegahan khusus (speciale preventie) yang mempunyai tujuan agar penjahat tidak mengulangi perbuatannya. Pelaku tindak pidana di kemudian hari akan menahan diri agar tidak berbuat seperti itu lagi, karena pelaku merasakan bahwa pidana merupakan penderitaan sehingga pidana itu berfungsi mendidik dan memperbaiki.

Dalam RUU KUHP, tujuan pemidanaan ditentukan sebagai berikut: mencegah dilakukannya tindak pidana dengan menegakkan norma hukum demi pengayoman masyarakat; memasyarakatkan terpidana dengan mengadakan pembinaan sehingga menjadi orang yang baik dan juga berguna; menyelesaikan konflik yang ditimbulkan oleh tindak pidana, memulihkan keseimbangan, dan mendatangkan rasa damai dalam masyarakat; dan membebaskan rasa bersalah pada para terpidana. Pemidanaan tersebut tidak ditujukan untuk menderitakan dan merendahkan martabat manusia (Pasal 54 RUU KUHP, Kementerian Hukum dan Hak Asasi Manusia, 2006/2008).

\section{Perumusan Tindak Pidana: Pola Pemidanaan}

Sebelum ke cara perumusan tindak pidana dalam suatu undang-undang, perlu dipahami terlebih dahulu mengenai pola pemidanaan. Pola pemidanaan yang digunakan selama ini pada umumnya mengacu pada KUHP atau pendapat para ahli hukum pidana yang telah melakukan pengelompokan atau penggolongan tindak pidana. Wirjono Prodjodikoro misalnya, telah mengelompokkan tindak pidana yang ditentukan dalam KUHP secara kualitatif dengan cara melihat pelanggaran berbagai kepentingan yang dilindungi (Wirjono Prodjodikoro, 1980:4-9). Menurut Wirjono Prodjodikoro, cara penggolongan tindak pidana perlu dilihat dari kepentingan yang dilindungi, meliputi: kepentingan oknum ataupun pribadi; kepentingan masyarakat; dan kepentingan negara.

Kejahatan terhadap kepentingan pribadi ataupun oknum (Bab XIII s.d. Bab XXVII dan Bab XXX KUHP) dibagi ke dalam: tindak pidana terhadap kekayaan orang (Bab XXII s.d. Bab XXVII, dan $\mathrm{XXX)}$; tindak pidana terhadap nyawa dan tubuh orang (Bab XV, Bab XVII, Bab XIX, Bab XX, Bab $\mathrm{XXI}$ ); tindak pidana terhadap kehormatan orang (Bab XIII, Bab XVI, Bab XVII); dan tindak pidana kesopanan (kesusilaan) (Bab XIV). Selanjutnya, kejahatan terhadap kepentingan masyarakat (Bab
V, VI, VII, IX, X, XI, XII dan XXIX KUHP) dibagi ke dalam: membahayakan keadaan (Bab V, VI, VII, XXIX) dan pemalsuan (Bab IX, X, XI, XII). Kejahatan terhadap kepentingan negara (Bab I, II, III, IV, VIII dan XXVIII) dibagi ke dalam: kedudukan negara (Bab I, II, III, IV) dan tindakan-tindakan alat negara (Bab VIII, XXVIII).

Dalam skema yang disusun oleh Zamhari Abidin, dikemukakan bahwa tugas hukum pidana adalah melindungi kepentingan hukum (rechtsbelangen) yang digolongkan ke dalam perlindungan terhadap nyawa, badan, kehormatan, kebebasan, dan kekayaan. Di Jerman kepentingan hukum terdiri atas hak-hak (rechten), keadaan hak (rechtstoestand), hubungan hukum (rechtsbetrekking), juga terdiri atas berbagai lembaga-lembaga kemasyarakatan (maatschappelijke instellingen) (Zamhari Abidin, 1986:4-15).

Satochid Kartanegara mengartikan kepentingan hukum adalah kepentingan yang harus dijaga agar supaya tidak dilanggar, dan yang kesemuanya itu ditujukan guna kepentingan masyarakat. Jadi tiap kepentingan masyarakat itu tidak dapat dibiarkan diganggu. (Satochid Kartanegara, hal. 79) Satochid lebih lanjut mengatakan bahwa, ada tiga macam kepentingan hukum (rechtsbelangen) yang harus dilindungi, antara lain yaitu kepentingan perseorangan (individuele belangen), dan kepentingan masyarakat (maatschappelijke belangen), dan juga kepentingan negara (staatsbelangen).

Satochid berpendapat, bahwa sekalipun dikenal 3 (tiga) penggolongan kepentingan hukum, akan tetapi sebenarnya kepentingan hukum itu tidak dapat dipisah-pisahkan. Hal ini disebabkan karena suatu kepentingan hukum baru dapat dianggap sebagai kepentingan perseorangan, bilamana kepentingan itu juga merupakan kepentingan masyarakat (het belang van het individu zal slechts als een rechtsbelang erkend worden, indien het tevens het belang van de maatschappij betekent). Kepentingan hukum yang demikian itu adalah kepentingan: jiwa (leven); badan (lijf); kehormatan (eer); kemerdekaan (vrijheid); dan harta benda (vermogen).

Adapun kepentingan hukum bagi masyarakat adalah ketenteraman dan keamanan (rust en orde) dan kepentingan hukum bagi negara adalah keamanan negara. Dari ketiga kepentingan hukum di atas yang tidak dapat dipisah-pisahkan, Satochid memberikan gambaran bahwa unsur hukum mengandung pula beberapa kepentingan, misalnya 'perkawinan' yang merupakan lembaga (bangunan) masyarakat yang di dalamnya tersimpul kepentingan masyarakat yaitu sifat yang agung dari perkawinan itu, juga adanya 
kepentingan dari suami-istri. Jika kita meninjau kepentingan negara yakni keamanan negara, maka kepentingan ini merupakan kepentingan masyarakat juga kepentingan perseorangan, misalnya nachtrust (istirahat malam), hal ini merupakan kepentingan perseorangan, namun juga kepentingan masyarakat. Satochid juga menambahkan bahwa, sungguhpun kepentingan itu tidak dapat dipisah-pisahkan, akan tetapi perpindahan dari accent-nya tidaklah khusus, karena "sesaat merupakan kepentingan perseorangan, namun pada saat lainnya merupakan kepentingan masyarakat". Pada dasarnya, setiap negara mempunyai kepentingan hukumnya sendiri-sendiri, meskipun pada umumnya kepentingan hukum itu sama, yaitu jiwa, badan, kehormatan, kemerdekaan, dan harta benda yang kesemuanya itu harus dijaga agar tidak dilanggar (Satochid Kartanegara, hal. 79-81).

Penggolongan di atas ini akan dijadikan acuan untuk mengaklasifikasi penentuan pola penentuan pidana dalam kelompok-kelompok kategori sehingga tampak perbedaan berat dan ringan serta kualifikasi kepentingan yang dilindungi. Pola penentuan pidana diklasifikasi dari tindak pidana berat (serius) sampai yang teringan untuk menunjukkan pembedaan jarak kualifikasi tindak pidana yang satu dengan yang lain. Pola pidana juga diklasifkasi terhadap penentuan pidana bagi korporasi, anak yang melakukan tindak pidana, undang-undang di luar KUHP, dan peraturan daerah.

Penentuan pola juga terkait dengan penentuan golongan ancaman pidana dengan bobot yang mana sangat ringan, ringan, sedang, berat, sangat berat (serius), sebagaimana telah disebutkan di atas, yang di dalamnya dapat ditentukan jenis pidananya yang dipilih berdasarkan penggolongannya. Ancaman dapat ditentukan penjara saja, penjara atau denda, atau denda saja, hal ini tergantung dari penggolongannya. Penggolongan yang ditentukan dalam 5 bobot di atas harus melihat kepentingan hukum apa yang dilindungi. Misalnya mengenai "zina" antara dua orang yang sudah kawin, kepentingan hukum apa yang dilindungi? Seperti tindak pidana korupsi, kepentingan hukum apa yang harus dilindungi, tidak sekadar aset negara, tetapi lebih daripada itu, misalnya nilai-nilai koruptif yang telah berbudaya di masyarakat. Remmelink berpendapat bahwa, ada kepentingan hukum yang ingin dilindungi itu karena merupakan immediatly danger (bahaya yang segera) yang berbeda dengan kepentingan yang ingin dilindungi karena expective danger (gevaarzetting delicten/membahayakan di masa yang akan datang), misalnya pembunuhan, pemerkosaan, pencurian, penyebaran pornografi atau riot (huru-hara dengan merusak barang atau membahayakan nyawa).

Remmelink mengingatkan, sebelum menentukan kategorisasi tindak pidana dan ancamannya, haruslah memahami makna tindak pidana itu sendiri. Tindak pidana adalah perilaku yang pada waktu tertentu dalam konteks suatu budaya, dianggap tidak dapat ditolerir dan harus diperbaiki dengan mendayagunakan sarana yang disediakan oleh hukum pidana (Remmelink, 2003:61). Lebih lanjut Remmelink juga menyatakan bahwa perbuatan tersebut dapat berupa gangguan atau menimbulkan bahaya terhadap kepentingan sehingga kepentingan tersebut harus dilindungi. Dalam rangka melindungi kepentingan hukum, pembuat undangundang perlu memfokuskan pada tindakan-tindakan yang bersifat menyakiti, merugikan, dan tindakan yang membayakan (nyawa, badan atau barang) lainnya.

Di bawah ini, pola-pola penentuan pidana yang ditentukan secara kualitatif dan kuantitatif dengan mendasarkan kepentingan hukum yang dilindungi berdasarkan gradasi dari yang terberat sampai yang teringan, kemudian pola-pola yang ditentukan terhadap subjek hukum pidana tertentu serta pola penentuan pidana dalam undang-undang di luar KUHP dan juga dalam peraturan daerah, dapat dikelompokkan sebagai berikut: pidana penjara tunggal tanpa pidana denda (serius atau sangat berat); pidana penjara dan pidana denda sebagai kumulatif pemberatan (berat); pidana denda sebagai alternatif pidana penjara (ringan); pidana denda tunggal (sangat ringan); pola pidana denda peraturan daerah (sangat ringan dan bersifat pelanggaran); pola pidana denda untuk korporasi (hanya denda dan biasanya pemberatan); pola pidana denda untuk anak (bisa juga untuk lansia); pola pidana denda undang-undang di luar KUHP (pelanggaran administratif yang dikriminalisasi yang pidananya relatif sangat ringan); pola pidana untuk kejahatan tanpa korban (ringan, dan dimaksudkan sebagai pencegahan umum serta rehabilitatif).

\section{Pembanding}

Pembentuk undang-undang, dalam penentuan pidananya sering membanding-bandingkan dengan undang-undang lain yang telah ada, atau dengan membandingkan dengan KUHP. Pembentuk undangundang juga sering bertanya, bagaimana mengukur secara pantas ancaman pidana yang dituangkan dalam Undang-Undang atau Perda? Untuk penyusunan Perda, telah ditentukan dalam UU Nomor 32 Tahun 2004 tentang Pemerintahan Daerah yakni maksimum (paling lama) pidana kurungan 6 (enam) bulan dan denda paling banyak Rp50 juta (lihat pula di UU 12 Tahun 
2011). Pembentuk Perda tinggal menentukan dari mulai 1 (satu) hari sampai 6 (enam) bulan kurungan atau dari Rp1 (satu) sampai Rp50 (lima puluh) juta untuk denda. Hal ini sudah barang tentu dikaitkan dengan ukuran berat dan ringannya pelanggaran.

Untuk undang-undang, pilihan ditentukan pada jenis pidana yang diatur dalam Pasal 10 KUHP. Hal ini juga didasarkan pada Pasal 103 KUHP. Jenis pidana yang ditentukan di dalam Pasal 10 KUHP adalah: 1. Pidana pokok: pidana mati; pidana penjara; kurungan; denda. 2. Pidana tambahan: pencabutan hak-hak tertentu; perampasan barang-barang tertentu; pengumuman putusan hakim.

Pembentuk undang-undang dapat menyimpang dari jenis pidana yang ditentukan di atas. Hal ini juga didasarkan pada Pasal 103 KUHP, karena di dalamnya memberikan kebebasan kepada pembentuk undangundang (di luar KUHP) untuk menyimpanginya. Penyimpangan pada umumnya hanya pada pidana tambahan, misalnya, pidana tambahan pencabutan izin bagi pengemudi kendaraan bermotor.

Di dalam KUHP tidak dikenal adanya minimum khusus atau pidana kumulatif. Pembentuk undangundang di luar KUHP sering pula menyimpangi dengan cara menentukan pidana penjara atau denda dengan minimum khusus. Hal ini dimaksudkan untuk mengurangi disparitas pidana dan lebih memberikan pemberatan pidana terhadap tindak pidana yang sangat membahayakan atau merugikan orang, misalnya undang-undang tentang pemberantasan tindak pidana terorisme atau korupsi.

Penentuan pidana pada korporasi juga merupakan penyimpangan, hal ini disebabkan karena KUHP hanya mengenal pemidanaan terhadap individu atau perseorangan. Asas-asas yang dikenal dalam Buku I KUHP, juga sering disimpangi oleh undang-undang, misalnya, percobaan tindak pidana yang pada dasarnya dikurangi seperti pidananya, namun dalam undangundang bisa ditentukan pidana yang sama dengan tindak pidana selesai atau tuntas (bukan percobaan). Demikian pula untuk tindak pidana pembantuan.

Untuk ukuran pidana, pembentuk undang-undang dapat membandingkan dengan ancaman pidana yang ditentukan dalam KUHP, undang-undang lain, atau konvensi internasional. Klasifikasi ancaman pidana dapat dilakukan dengan memilah-milah macam tindak pidana, seperti tindak pidana terhadap nyawa, badan, dan barang yang dicontohkan di atas.

Dalam hal pidana kurungan, telah ditentukan pengaturannya dalam KUHP (dalam Pasal 18-Pasal 23). Pidana kurungan diancamkan 1 (satu) hari1 (satu) tahun, dan pada umumnya untuk tindak pidana pelanggaran atau bukan kejahatan (tindak pidana ringan). Orang yang dijatuhi pidana kurungan dapat memperbaiki nasibnya dengan biaya sendiri, misalnya membawa tempat tidur sendiri. Pidana kurungan merupakan pengganti pidana denda, begitu sebaliknya. Dalam Undang-Undang Tindak Pidana Khusus, pengganti denda bisa dijatuhi pidana penjara (pengecualian atau penyimpangan).

Selain KUHP, perundang-undangan di luar KUHP dapat juga dijadikan pembanding, walaupun ancaman pidananya beragam, apalagi adanya undang-undang hukum pidana di luar KUHP atau orang mengatakan sebagai tindak pidana khusus. Sebagaimana kita ketahui bersama bahwa selama ini dikenal adanya macam undang-undang yang di dalamnya terdapat ketentuan pidana. Macam undang-undang tersebut adalah: a. undang-undang hukum pidana (seperti KUHP atau UU Korupsi); b. undang-undang hukum perdata (KUHPerdata); c. undang-undang hukum administrasi (mengatur perizinan atau kepegawaian); d. undang-undang organik (pembentukan institusi dan susunan organisasinya); e. undang-undang pengesahan (ratifikasi); f. undang-undang penetapan (APBN); g. undang-undang arahan atau pedoman (UU Tata Ruang); h. undang-undang campuran (administratif, keperdataan, arahan, dan/atau organik)

Macam undang-undang di atas yang tidak lazim dicantumkan ketentuan pidana adalah undang-undang pada huruf $d$, huruf e, dan huruf $f$, sedangkan yang huruf $b$, huruf $c$, huruf $g$, dan huruf $h$ dimungkinkan adanya ketentuan pidana. Untuk undang-undang huruf a, format atau sistematika ketentuan pidananya berbeda dengan format atau sistematika undang-undang huruf $\mathrm{b}, \mathrm{c}, \mathrm{g}$, dan huruf $\mathrm{h}$. Undang-undang hukum pidana, terutama undang-undang hukum pidana di luar KUHP, misalnya UU tentang Pemberantasan Tindak Pidana Korupsi, UU tentang Pemberantasan Tindak Pidana Perdagangan Orang, dan UU tentang Pemberantasan Tindak Pidana Terorisme, pada dasarnya bermateri muatan KUHP, namun karena baik secara materiel maupun formil menyimpang dari KUHP dan KUHAP, kemudian orang mengatakan undang-undang tersebut sebagai tindak pidana khusus. Penyimpangannya terletak pada penentuan ancaman pidananya (minimum khusus dan kumulatif), penentuan penyimpangan pada Buku I KUHP, penentuan penyimpangan pada hukum acaranya (KUHAP), dan penyimpangan pada format atau sistematika undang-undang di luar KUHP sebagaimana ditentukan dalam UU Nomor 12 Tahun 2011 (lampiran).

Undang-undang huruf $b$, huruf $c$, huruf $g$, dan huruf $h$ yang di dalamnya terdapat ketentuan pidana, 
para ahli hukum pidana berpendapat bahwa penentuan pidananya sebaiknya diancamkan relatif ringan karena pembentuk undang-undang melakukan kriminalisasi terhadap perbuatan administratif atau keperdataan. Bobot akan ancaman pidana terhadap perbuatan administratif atau keperdataan yang dikriminalisasi digantunkan pada sifat jahatnya perbuatan.

\section{Cara Perumusan Tindak Pidana}

Di dalam Undang-Undang Nomor 12 Tahun 2011 telah diatur bagaimana merumuskan ketentuan pidana (lihat lampiran angka 112 sampai 126). Di dalam lampiran disebutkan bahwa ketentuan pidana memuat rumusan yang menyatakan penjatuhan pidana atas pelanggaran terhadap ketentuan yang berisi norma larangan atau perintah. Dalam merumuskan ketentuan pidana perlu diperhatikan asas-asas umum ketentuan pidana yang terdapat dalam Buku I KUHP, karena ketentuan dalam Buku Kesatu berlaku juga bagi perbuatan yang dapat dipidana menurut peraturan perundang-undangan lain, kecuali jika oleh UndangUndang ditentukan lain (Pasal 103 KUHP).

Dalam rangka menentukan lamanya pidana atau banyaknya denda, perlu dipertimbangkan mengenai dampak yang ditimbulkan oleh tindak pidana dalam masyarakat serta unsur kesalahan pelaku. Ketentuan pidana ditempatkan dalam bab tersendiri, yaitu bab ketentuan pidana yang letaknya sesudah materi pokok yang diatur atau sebelum bab ketentuan peralihan. Jika bab ketentuan peralihan tidak ada, letaknya adalah sebelum bab ketentuan penutup.

Jika di dalam peraturan perundang-undangan tidak ada pengelompokan bab per bab, ketentuan pidana akan ditempatkan dalam pasal yang terletak langsung sebelum pasal atau dalam beberapa pasal yang berisi ketentuan peralihan. Jika tidak ada pasal yang berisi ketentuan peralihan, ketentuan pidana diletakkan sebelum pasal atau beberapa pasal yang berisi ketentuan penutup. Ketentuan pidana hanya dimuat dalam Undang-Undang, Peraturan Daerah Provinsi, dan Peraturan Daerah Kabupaten/Kota.

Rumusan ketentuan pidana harus menyebutkan secara tegas norma larangan atau norma perintah yang dilanggar dan menyebutkan pasal atau beberapa pasal yang memuat norma tersebut. Dengan demikian, perlu dihindari pengacuan kepada ketentuan pidana peraturan perundang-undangan lain.

Selain itu, perlu dihindari akan adanya pengacuan kepada KUHP, jika elemen atau unsur-unsur dari norma yang diacu tersebut tidak sama. Hindari pula penyusunan rumusan sendiri yang berbeda atau tidak terdapat di dalam norma-norma yang diatur dalam pasal atau beberapa pasal sebelumnya, kecuali untuk undang-undang mengenai tindak pidana khusus.

Jika ketentuan pidana berlaku bagi siapapun, subjek dari ketentuan pidana dirumuskan dengan frasa setiap orang, yang sengaja dan tanpa hak menggunakan merek yang sama pada keseluruhannya dengan merek terdaftar milik orang lain atau badan hukum lain untuk barang atau jasa sejenis yang diproduksi dan atau diperdagangkan (Pasal 81 KUHP).

Jika ketentuan pidana hanya berlaku bagi subjek tertentu, subjek itu dirumuskan secara tegas, misalnya, orang asing, pegawai negeri, saksi (Lihat Pasal 143 Undang-Undang Nomor 35 Tahun 2009 tentang Narkotika).

Sehubungan adanya pembedaan antara tindak pidana kejahatan dan tindak pidana pelanggaran di dalam Pasal 33 Kitab Undang-Undang Hukum Pidana, rumusan ketentuan pidana harus menyatakan secara tegas kualifikasi dari perbuatan yang diancam dengan pidana itu sebagai pelanggaran atau kejahatan.

Rumusan ketentuan pidana harus menyatakan dengan tegas akan kualifikasi pidana yang dijatuhkan itu apakah bersifat kumulatif, alternatif, atau kumulatif alternatif. Perumusan dalam ketentuan pidana harus menunjukkan dengan jelas unsur-unsur perbuatan pidana bersifat kumulatif atau alternatif.

Jika suatu peraturan perundang-undangan yang memuat ketentuan pidana akan diberlakusurutkan, ketentuan pidananya harus dikecualikan, mengingat asas dalam Pasal 1 ayat (1) KUHP yang menyatakan bahwa ketentuan pidana tidak boleh berlaku surut.

Ketentuan hukum pidana bagi tindak pidana yang merupakan pelanggaran terhadap kegiatan bidang ekonomi dapat diatur tersendiri di dalam undangundang yang bersangkutan, tetapi cukup mengacu kepada undang-undang yang mengatur mengenai tindak pidana di bidang ekonomi, misalnya, UndangUndang No. 7 Drt. Tahun 1955 tentang Pengusutan, Penuntutan, dan Peradilan Tindak Pidana Ekonomi.

Tindak pidana dapat dilakukan oleh perorangan ataupun oleh korporasi. Pidana terhadap tindak pidana yang dilakukan oleh korporasi dijatuhkan kepada: a. Badan hukum antara lain perseroan, perkumpulan, yayasan, atau koperasi; dan/atau; b. Pemberi perintah untuk melakukan tindak pidana atau yang bertindak sebagai pimpinan dalam melakukan tindak pidana.

\section{Perumusan Elemen atau Unsur Tindak Pidana}

Di dalam Undang-Undang No. 12 Tahun 2011 belum dicontohkan bagaimana merumuskan suatu unsur-unsur tindak pidana yang baik dan rinci, padahal penentuan unsur tindak pidana sangat penting terkait 
dengan kepastian dapat dipidananya seseorang atau pelaku. Unsur tindak pidana yang telah kita ketahui adalah unsur tindak pidana subjektif dan unsur tindak pidana objektif.

Unsur tindak pidana yang subjektif merupakan unsur yang melekat pada diri pelaku tindak pidana, termasuk unsur yang terkandung di dalam hatinya, yaitu: (niat,maksud dan tujuan). Sedangkan unsur tindak pidana yang objektif adalah unsur yang ada hubungannya dengan tindakan pelaku tindak pidana (perbuatan, tingkah laku atau aktivitas).

Unsur-unsur subjektif pada umumnya dirumuskan dengan kata sengaja atau tidak sengaja (alpa) atau dengan rencana terlebih dahulu. sebelum unsur unsur dalam perbuatan atau tindakan yang dilakukan pelaku. Kadangkala juga dirumuskan dengan frase dengan maksud atau dengan tujuan setelah unsurunsur perbuatan/tindakan yang dilakukan pelaku. Pencantuman unsur-unsur subjektif di atas membawa konsekuensi adanya kewajiban bagi penegak hukum untuk membuktikan sikap batinnya.

Beberapa perbuatan atau tindakan kadangkala tidak memerlukan unsur-unsur subjektif, karena bilamana dilihat dari perbuatan atau tindakan itu sendiri sudah dapat dikatakan mengartikan suatu kesengajaan, misalnya, Pasal 362 KUHP. Dalam Ketentuan Pasal 362 tidak didahului adanya kesengajaan, karena pada saat pelaku mengambil barang milik orang lain secara melawan hukum itu dapat dikatakan bahwa perbuatan tersebut mengambil barang milik orang lain itu adalah dengan sengaja.

Pada saat pembentuk undang-undang menentukan adanya kata sengaja pada perbuatan atau tindakan tertentu, apakah selalu diperlukan adanya rumusan lain untuk melengkapi perbuatan sengaja dengan kata alpa pada ayat-ayat berikutnya. Hal ini tergantung keinginan pembentuk undang-undang, dengan catatan bahwa perbuatan atau tindakan yang mengikutinya memang bisa terlaksana dengan unsur alpa. Perbuatan pemerkosaan, misalnya, tidak mungkin ditambahkan unsur subjektif adanya alpa.

Untuk unsur objektif, perumusan perbuatan atau tindakan hendaknya dilakukan dengan hati-hati. Jika diinginkan adanya beberapa perbuatan, sebaiknya tiaptiap perbuatan tersebut disusun secara kesejajaran atau sepadan sehingga tidak menimbulkan ketimpangan antara perbuatan yang satu dengan perbuatan yang lainnya karena hal ini terkait dengan penentuan bobot ancaman pidana. Jika perbuatan yang dirumuskan lebih daripada satu, cukup digunakan kata "atau" untuk menunjukkan satu perbuatan saja sudah dapat dikenakan pidana karena telah memenuhi unsur.

\section{Kasus-Kasus dalam Perumusan Sanksi Pidana}

Berbeda dengan Undang-Undang No. 24 Tahun 2007 tentang Penanggulangan Bencana, yang mana menentukan pidana denda secara minimum khusus tanpa memperhatikan proporsionalitas jarak antara minimum khusus dan maksimumnya sehingga hakim kesulitan untuk memberikan atau menjatuhkan pidana sesuai dengan keyakinannya atau berdasarkan keadilan masyarakat. Ketentuan tersebut menentukan ancaman pidana dengan gradasi.

Jarak antara ancaman pidana minimum khusus dan pidana maksimum begitu dekat (pendek) sehingga hakim hanya mempunyai pilihan yang mana terbatas untuk menjatuhkan pidana. Jarak perbedaan 2 (dua) tahun antara pidana penjara paling singkat 6 (enam) tahun, atau paling lama 8 (delapan) tahun, akan mempersulit hakim dalam hal memutus atas dasar keyakinan atau pengamatannya dalam pemeriksaan di sidang pengadilan berdasarkan keadilan sesuai dengan irah-irah "Demi Keadilan Berdasarkan Ketuhanan Yang Maha Esa".

Kriminalitas dalam hukum pidana atau alasan Lex Specialis, contohnya dalam Pasal 35 dan pada Pasal 36 Undang-Undang No. 42 Tahun 1999 tentang Fidusia, dan pada Pasal 36 dan Pasal 37 UndangUndang No. 12 Tahun 2006 tentang Kewarganegaraan, dan pada Pasal 71, Pasal 72, dan Pasal 73 UndangUndang No. 26 Tahun 2007 tentang Penataan Ruang menentukan ketentuan pidana dengan alasan undangundang khusus sehingga perbuatan memalsukan atau memberikan keterangan palsu (menyesatkan), diancam dengan minimum khusus. Sedangkan untuk pelanggaran perizinan yang ditentukan UndangUndang No. 26 Tahun 2007 tentang Penataan Ruang, diberikan ancaman minimum khusus juga, walaupun perbuatan tersebut semata-mata karena pelanggaran administratif.

Dalam Pasal 36 dan Pasal 37 Undang-Undang No. 26 Tahun 2000 tentang Pengadilan Hak Asasi Manusia yang memberikan ancaman maksimum umum atau melebihi pola atau patokan yang ditentukan dalam KUHP. Pasal 12 KUHP menentukan bahwa: Pidana penjara lamanya seumur hidup atau selama waktu tertentu. Pidana penjara waktu tertentu sekurangkurangnya satu hari dan paling lama 15 (lima belas) tahun berturut-turut.

Di dalam Pasal 27 dan Pasal 45 Undang-Undang No. 11 Tahun 2008 tentang Informasi dan Transaksi Elektronik, terdapat ketentuan pidana, dan ketentuan untuk ancaman pidana tersebut dirapel, atau disamakan untuk tindak pidana yang mana sebenarnya bobotnya tidak sama. 


\section{PENUTUP}

\section{Kesimpulan}

Demi menjawab pertanyaan mengenai perlunya pidana dalam suatu tindak pidana, dapat terjawab dengan cara mengkaji apakah suatu pidana yang diancamkan itu sesuai dengan tindak pidana yang dilakukan. Dengan mendalami bagaimana suatu pidana itu sesuai dengan tindak pidana yang dilakukan oleh pelaku tindak pidana. maka berbicara mengenai kesesuaian atas dasar tindakan dan hukuman, yang mana hal ini perlu dikaji karena kriminolog selalu mengingatkan bahwa inti dari kejahatan itu adalah penyimpangan tingkah laku. Jadi tidak seharusnya tiap kejahatan selalu dikaitkan dengan hukuman, walaupun pidana itu dilihat sebagai suatu ganjaran negatif terhadap setiap perilaku menyimpang yang dilakukan oleh warga masyarakat, ataupun dilihat dari segi manfaat atau kegunaannya. Penjatuhan pidana pada hakekatnya adalah sebagai sarana mewujudkan keadilan. Keadilan yang dicari disini dalam rangka tindakan preventif, membawa kebaikan, mencari pembenaran dan juga berkaitan dengan pandangan forward-looking.

\section{Rekomendasi}

Pembentuk undang-undang agar berhati-hati dalam menentukan pidana, baik ancaman pidana maupun cara perumusannya. Sedapat mungkin, pidana yang diancamkan harus memperhatikan rasa keadilan dalam masyarakat (dengan cara menghitung akibat tidak pidana yang mungkin timbul atau yang ditimbulkan) dan segi manfaat atau kegunaannya. Di negara-negara lain, sudah dikembangkan adanya sanksi alternatif (denda atau kerja sosial) dan keadilan restoratif. Suatu hal yang perlu dicoba dalam penentuan sanksi pidana dalam undang-undang.

\section{DAFTAR PUSTAKA:}

Arief, Barda Nawawi, 2002, Bunga Rampai, Kebijakan Hukum Pidana, Bandung: Citra Aditya Bakti. 2008, Bunga Rampai, Kebijakan Hukum Pidana, Perkembangan Penyusunan Konsep KUHP Baru, Jakarta: Kencana Prenada Media Grup.

Duff, Antony and David Garland, 1994, A Reader on Punishment, New York: Oxford University Press.

Kaplan, John, 1973, Criminal Justice, New York: The Foundation Press Inc. Mineola.

Kartanegara, Satochid, Kumpulan Kuliah Bagian Satu, Balai Lektur Mahasiswa.

Lamintang, P.A.F., 1983, Dasar-dasar Hukum Pidana Indonesia, Bandung: Sinar Baru. , 1985, Hukum Penitensier Indonesia, Edisi Pertama, Bandung: Armico.

Muladi, 1992, Lembaga Pidana Bersyarat, Bandung: Alumni.

Packer, Herbert L., 1968, The Limits of The Criminal Sanction, California: Stanford University Press.

Remmelink, Jan, 2003, Hukum Pidana - Komentar atas Pasal-pasal Terpenting dari KUHP Belanda dan Pidananya dalam KUHP Indonesia, Jakarta: Gramedia Pustaka Utama.

Roeslan, S., 1983, Hukum Pidana sebagai Konfrontasi Manusia - Manusia, Jakarta: Ghalia Indonesia.

Sudarto, 1983, Hukum dan Hukum Pidana, Bandung: Alumni.

Suringa, D. Hazewinkel, 1975, Inleiding tot De Studie van Het Nederlandse Strafrecht, Groningen: H.D. Tjeenk Willink B.V. 